\title{
Catalyzing Development of Best Practice Guidelines for Community-managed Health Programs: Case Study of a Community-Academic Partnership
}

\author{
Jaifred Christian F. Lopez, ${ }^{1,2}$ Ruben N. Caragay, ${ }^{3}$ Isidro C. Sia, ${ }^{4}$ Jennifer S. Madamba, ${ }^{5}$ \\ Dulce Corazon Velasco, ${ }^{5}$ Hilton Y. Lam, ${ }^{6}$ Leonardo R. Estacio ${ }^{7}$ and Edna Estifania A. Co ${ }^{8}$ \\ Office of Research and Innovation, and College of Medicine, San Beda University Manila \\ ${ }^{2}$ Tambalista, Inc., Quezon City, Philippines \\ ${ }^{3}$ College of Medicine, Bicol University \\ ${ }^{4}$ Department of Pharmacology and Toxicology, College of Medicine, University of the Philippines Manila \\ ${ }^{5}$ Integrative Medicine for Alternative Health Care Systems \\ ${ }^{6}$ Institute of Health Policy and Development Studies, National Institutes of Health, University of the Philippines Manila \\ ${ }^{7}$ College of Arts and Sciences, University of the Philippines Manila \\ ${ }^{8}$ Center for Integrative and Development Studies
}

\begin{abstract}
Background. There is a need to standardize community health practices, while still adhering to principles of community involvement, to ensure social acceptability and equitable access to health services. A set of Best practice guidelines (BPGs) were thus developed through a community-academic partnership (CAP) between the Integrative Medicine for Alternative Healthcare Systems Philippines, Inc. and its affiliated community-managed health programs (CMHPs), the University of the Philippines, and Bicol University.
\end{abstract}

Objective. This study aimed to report the process and insights gained from the crafting of the BPGs.

Methods. The BPGs were developed using a community-based participatory research approach and focused on top ten (10) diseases based on local prevalence and experiences of its CMHPs.

Results. BPGs were developed for eight (8) communicable diseases (common cold/cough, influenza, measles, pulmonary tuberculosis, acute gastroenteritis, amebiasis, scabies, and intestinal parasitism); and two (2) noncommunicable diseases (diabetes and hypertension), which also provided information on signs and symptoms, initial referral criteria, management, and, where appropriate, specific use of medicinal plants, acupressure, and traditional massage. Emerging issues from this project include how community involvement led to the development of BPGs, the need to update its content, its potential application as a model for costing public health interventions, its anticipated benefits to health workers, the state of local health service delivery, and how the project epitomizes the ideal concept of community-academic partnerships.

Conclusion. As a CAP project, this process holds promise as a catalyst for stakeholder engagement and health service delivery improvement. Further studies are necessary to map out other potential challenges and success factors, especially the socio-cultural, political, and health impact of CAPs.

Key Words: community-academic partnership, community-managed health programs, integrative health care, practice guidelines, primary health care

\section{INTRODUCTION}

Corresponding author: Ruben N Caragay, MD, PhD College of Medicine

Bicol University, Daraga, Albay, Philippines

Email: bicolumedicine@gmail.com
Community involvement has been actively promoted as a key component of primary health care towards achieving "health for all" and has been billed by the World Health Organization's 1978 Alma Ata Declaration as an approach to provide acceptable, affordable, and accessible health care 
services in resource-limited areas, while equally emphasizing the importance of scientific validity, safety, and efficacy. ${ }^{1}$ However, community health practices as well as health programs tend to be implemented with varying degree of deviation from established clinical practice guidelines depending on available facilities, human resources, and other underlying factors. ${ }^{2}$ Because of the need to ensure the "scientific soundness" of community health practices, ${ }^{1}$ there is a need to standardize them through the development of best practice guidelines (BPGs), which are "systematically developed statements to assist practitioner and patient decisions about appropriate health care for specific clinical circumstances," ${ }^{3}$ and require collaboration with other stakeholders, both to ensure adequate representation for building consensus, and to harmonize these practices with expert opinion, local circumstances, and scientific evidence. This case study showcases how a community-academic partnership can successfully instigate a sustainable and socially acceptable development process for best practice guidelines.

Community-academic partnerships (CAPs) are formed between members of a community or organization and the academe that are bound by a common advocacy or purpose. They have been described as collaborations with "equitable control", whose primary interest and specific aims are to achieve solutions to community specific issues. ${ }^{4}$ Notably, a 2016 review of published literature by Drahota and colleagues on CAPs reveals that health-oriented CAPs have been mostly focused on a single disease entity or health-related advocacy, and did not utilize a practitioner-focused approach in addressing health needs encountered in areas being served by community-managed programs. ${ }^{4}$ CAPs included in this review included experiences in developing programs for mental health, care of persons with disabilities, environmental management, and breast cancer screening. ${ }^{4}$

Meanwhile, in the Philippines, there have been past initiatives for the standardization of curative health practices in community-managed health programs (CMHPs). As early as 1968, CAPs have been documented to implement training programs for health workers, as in the case of the Katiwala project in Mindanao ${ }^{5}$ and the development of an indigenous health care system among the Hanunuo Mangyans in Mindoro island in $1988 .{ }^{6}$ At the national level, the barangay (village) health workers (BHWs) program, which recruits health volunteers to assist in the functions of primary health care centers, aimed to deploy community-based advocates for health programs to increase local acceptability and improve implementation, but no recent studies have been found that document the extent of standardization of their practice. For instance, a 1993 case study by Lacuesta, Sarangani, and Amoyen was only able to feature how BHWs are trained to counsel mothers and families on the use of health center facilities, especially family planning, ${ }^{7}$ and a 1998 case study by Arroyo noted how a foreign aid-assisted program in Balayan, Batangas province capacitated BHWs to assist in nutrition programs, family planning services, and environmental health advocacy. ${ }^{8} \mathrm{~A}$ common theme in these local efforts is the development of health interventions that are acceptable to the community, a concept which has been articulated as a result of a mix of supply-side factors (e.g., location, characteristics, payment scheme and services offered in health centers; ethnicity of health workers) and demand-side factors such as awareness on health programs, and the level of community participation. ${ }^{9}$ However, details of these concerns vary across localities, thus necessitating a method of research that adequately considers realities and underlying issues that affect communities. A response to this need, community-based participatory research (CBPR) has been developed as a way to "involve [communities] in each stage of the research from the study's conception to its design, analysis and communication of results, ${ }^{10}$ thus building a sense of community ownership, reliability of data, and relevance of results. ${ }^{11}$

\section{The CMHP network of INAM}

Founded in 1984, the Integrative Medicine for Alternative Health Care Systems (INAM) Philippines, Inc. (formerly the Acupuncture Therapeutic and Research Center) is a non-stock, non-profit organization which started as a training center for acupuncture (and other traditional Chinese medicine modalities) and Philippine traditional medicine. ${ }^{12}$ It has organized and trained communitymanaged health programs (CMHPs) that provide preventive and curative health services that integrate conventional Western medicines, the use of Philippine medicinal plants, acupuncture and acupressure, and tui na (Chinese traditional health massage); and awards certifications in acupuncture training that is recognized by the Philippine Institute for Traditional Training and Alternative Health Care (PITAHC).

More importantly, through the help of institutional linkages and a partnership with the University of the Philippines (UP) and Bicol University, an Emerging InterDisciplinary Research (UP-EIDR) project was established, which served as venue for the community-based participatory research activities and the BPG development process, which is the focus of this article.

The general aim of the project was to develop best practices guidelines (BPGs) for the management of top ten diseases based on the local disease prevalence and the experiences of CMHPs in providing equitable access to essential health services, by utilizing a community-based participatory approach.

\section{METHODS}

The project was executed in two phases: the process of developing the BPGs, and the validation process. Cutting across these two phases was a feedback mechanism in which comments were elicited from $\mathrm{CHW}$ sho were implementing the guidelines, members of the academe including the authors, local and national health authorities, and other organizations. 


\section{BPG development}

To form the local evidence base of developing the BPGs, INAM Philippines facilitated the organization of research teams, which were composed of CHWs and community health managers (CHMs), selected on the basis of: 1 ) commitment to the project, 2) basic skills in communication, and 3) credibility and respectability in the community. Represented in this effort were 39 barangays from 12 municipalities located in these provinces: Rizal, Sorsogon, Negros Occidental, Misamis Occidental, North Cotabato, and Sulu. A conceptual framework was then developed collaboratively, which emphasized accountability of involved stakeholders and agencies, community participation, and a sustainable health care system. Five overarching principles were also chosen in developing the guidelines, influenced by the Primary Health Care Declaration of Alma Ata: quality, availability, accessibility, affordability, and acceptability. Participants of the mentoring session also produced an action plan that aimed to identify gaps, health needs, and potential solutions to address these issues in the community setting.

Subsequently, a list of top ten (10) diseases in the community setting were identified for inclusion in the best practice guidelines manual, based on data collected from households in communities served by the CMHPs, with priority for diseases that are manageable in the community setting. Results from this survey, as well as records from community health workers and previous Philippine Integrative Medicine (PIM) trainings, subsequently guided the compilation of best practices from conventional medical references such as the Merck Manual, Harrison's Principles of Internal Medicine, and journal articles, as well as guidelines issued by the World Health Organization (WHO), Department of Health (DOH), Centers for Disease Control and Prevention, and Philippine medical specialty societies. Since traditional medicine was an important element in the PIM training program, a review of ethnopharmacology studies was also done using these databases: Traditional Knowledge Digital Library on Health, Natural Standards/Natural Medicine Database, National Center for Complementary and Alternative Medicine, herbs. ph (a database of researches on herbs and supplements in the Philippines), and the Health Research and Development Information Network (HERDIN). Pre-testing of the initial draft document was made through focus group discussion among communities of third-party organizations based in Nueva Ecija and Pangasinan, which were not involved in the development process.

Eventually, the draft documents were supported by inputs generated during a writing workshop that involved 12 CMHP managers, of which two (2) were chosen from each of six (6) CMHPs that participated in the baseline household survey. They were selected based on their extensive experience in health services and represented these municipalities: Tanay in the province of Rizal, Gubat and Sorsogon City in Sorsogon province, Murcia and Sipalay in Negros Occidental province, Sinacaban in Misamis Occidental province, Midsayap in North Cotabato province, and Patikul and Jolo in Sulu province. These managers cum health workers provided information on various practices utilized in their service areas that integrated traditional medicine and conventional biomedicine. Copies of the drafts that were produced in the workshop were then distributed prior to a planned assembly of CHWs, for study and pre-testing in CMHPs.

\section{BPG validation}

Activities in this phase included a CHW assembly, a community participatory research activity (i.e., participant observation), and another writing workshop. Gathering 70 CMHP managers and CHWs from 38 CMHPs, the $\mathrm{CHW}$ assembly served as a venue to validate the drafts and generate insights from other stakeholders. In addition, two (2) municipal health officers and 14 staff members of partner organizations coming from non-government organizations (NGOs), church programs, and government health centers were also present in the three-day assembly. Representatives came from various units of the $\mathrm{DOH}$ central office, such as the National Center for Health Facility Development, National Center for Disease Prevention and Control, Family Health Office, and the Bureau of Local Health Development. Representatives from the Philippine Health Insurance Corporation (PhilHealth, the national health insurance agency) and the Philippine Institute of Traditional and Alternative Health Care were also in attendance, as well as other representatives from the Misamis Occidental Provincial Health Office and the Quezon City Committee on Health.

CMHP managers who had participated in the preceding writing workshop described the content of the BPGs, how they were developed, the basis for the choice of the ten diseases, and the common framework they used in the choice of treatment modalities. Subsequently, a panel of six (6) reactors gathered from the pool of represented agencies and organizations gave comments on the BPGs in terms of safe use, beneficial use, acceptability, affordability, accessibility, and availability, as well as other implementation-related aspects related with their respective offices. The previously mentioned partner organizations and government stakeholders also provided disease-specific recommendations (Table 4). Group discussions followed, which ultimately produced a draft resolution binding all representative CMHPs to adopt and improve further the Best Practice Guidelines, with the assistance of partner organizations and the academe. Copies of the draft resolution were then distributed and discussed by the participants. The resolution approved and signed by all stakeholders present during the CHW assembly formed the basis for developing a system for validation of BPGs, and their monitoring and evaluation.

To ensure applicability of the BPGs, potential difficulties in implementation that were previously identified by the panelists during the first writing workshop were documented and validated by previously mentored community-based 
research teams through participant observation on whether communities experience equitable access to quality or improved health services through the CMHPs, and their feasibility within local government health systems. To facilitate the research in these areas, the research teams and the UP-EIDR team strengthened institutional linkages with and provided copies of draft BPGs to concerned offices in the barangay, municipal and provincial government, as well as with the regional and national offices of the Department of Health. Study sites for this phase were the CMHP in the municipality of Murcia, Negros Occidental, which was included in the original cohort of CMHPs in the earlier phases of the project, and the CMHP from the municipality of Aloran in Misamis Occidental province, an addition to the project. The BPGs were used as a standard for the management of ten diseases in the CMHPs, and experiences collected from this project phase served as basis for developing local implementation arrangements for referral networks; and PhilHealth accreditation, member registration, and financial support.

Additionally, while being guided by the inputs generated by the aforementioned validation, a second writing workshop was also held to revise the BPGs based on the suggestions and comments of the panel of reactors and participants. The same representatives from the 6 CMHPs in the first writing workshop participated in this activity, with the addition of two representatives from Aloran municipality. Comments and suggestions generated from the validation research and the writing workshops were further considered in coming up with the final version of the BPGs. Informed by results from the previous project phases, an information system was subsequently developed to enable documentation and future analysis of health services being provided to the community, as well as the implementation of the BPGs. Three (3) data gathering forms were designed:1) patient information record, 2) list of health education activities conducted, and 3) list of plants cultivated. These forms were designed to facilitate periodic summaries semi-annually and annually.

In summary, the project used methods that aimed to ground the BPGs on local disease prevalence, current scientific evidence, and insights from local and national health stakeholders, while catalyzing community participation.

\section{RESULTS}

The development and validation of the BPGs allowed for scoping of various considerations for the diagnosis, management, and monitoring of common community illnesses, and generated perspectives from various offices and organizations that are also involved in primary health care and integrative medicine. This section encompasses insights generated during the BPG development and validation phases, while detailed results from the individual community participatory research activities are beyond the scope of this article and are therefore not included in this section. Drafts resulting from the BPG development phase and the first workshop activity included steps on how to identify a patient's condition, how to distinguish cases that can be treated in the community setting and those that warrant referral to a higher-level health facility, and appropriate treatment methods. Table 1 shows the ten (10) diseases identified in the project, as well as the referral criteria and initial management (including appropriate home remedies, traditional medicines, and/or essential western medicines), that were included in the best practice guidelines, while Table 2 and Table 3 summarize recommended medicinal plants and acupressure techniques, respectively. Other information that formed part of the guidelines include initial signs and symptoms, pictures of medicinal plants, and diagrams of acupressure and tui na massage techniques.

Meanwhile, the CHW assembly, which served as a venue for validation of the BPGs, provided the opportunity for CHWs to discuss their experiences in implementing the draft BPGs. CHMP managers and CHWs agreed that the implementation of BPGs further enhanced their capability as CHP managers, and believed that the process strengthened the case for their recognition for accreditation as PhilHealth health service providers, which enables access to its benefits for facilities improvement and financial assistance. This is further supported by the specificity of interventions listed in the guidelines, which facilitate costing and thus possible future reimbursement by PhilHealth or the local government unit. Furthermore, the BPGs provided a favorable environment for applying communities' traditional health practices, to make the CMHPs more responsive, and confident in using locally available medicinal plants for treatment. Because of this, participants were of the opinion that through the BPGs, indigenous practices and medicinal resources could be better preserved and sustained.

The different stakeholders also provided comments during the CHW assembly, which can be found in Table 4 . Broadly, reactors commented on the BPGs using the five (5) overarching principles specified in the project's conceptual framework: quality, availability, affordability, accessibility, and acceptability. Feasibility of implementation was also assessed. General comments on the BPG format gathered from stakeholders in attendance included recommendations on format, such as producing the BPGs in guideline form, writing it in vernacular languages with verified translation, and extensive use of graphics and pictures, especially important in identifying the medicinal plants for the BPGs as well as specific steps for acupressure technique. Meanwhile, content-related general recommendations comprised of the following: 1) consultations should be done with concerned medical societies to ensure consistency with clinical practice guidelines currently followed by clinicians, 2) the inclusion of information on etiology of the 10 diseases, and how initial symptoms may be relieved, and 3) the inclusion of detailed information on the use of medicinal plants, acupressure and massage, such as duration or preparation. Subsequently, 
as a result of the validation research, which provided more practical insights on the use of the BPGs, the following offices provided comments during the second writing workshop activity: the health offices of Negros Occidental and Misamis Occidental, the individual municipal health offices of the study sites, and the $\mathrm{DOH}$ regional offices that provide technical assistance to the CMHPs: Western Visayas (Region VI) and Northern Mindanao (Region X). Comments from this final validation were then considered in the final version of BPGs that were disseminated to all CMHPs. Results from the monitoring and validation phase are currently being compiled as an ongoing effort to sustain the progress of the project and are beyond the scope of this article. It is expected that the monitoring system will guide CMHPs in updating the BPGs, especially the medicinal plants and traditional practices employed in the community setting, as well as information on patient demographics, risk factors, and effective methods for information dissemination.

\section{DISCUSSION}

Despite having a well-documented history of the development of community health programs in the country, to our knowledge this study is one of the first from the
Philippines that focuses on developing best practice guidelines through building community capacity for research and needs analysis and eliciting collaborative input from a wide variety of stakeholders in government, the NGO sector, and the academe. It must be pointed out that while this collaborative approach was already advocated by the Alma Ata Declaration itself when it emphasized that "the people have the right and duty to participate individually and collectively in the planning and implementation of their health care," " there have been few documented experiences in operationalizing this ideal within the organizational structure of local health systems in the Philippines. Previous studies reveal that majority of community-oriented approaches documented in academic literature were initiated by cause-oriented groups with a predetermined programmatic approach, mostly in response to a specific health need either initiated by the community, by the academe, by other stakeholders, or similarly to this project, through community-academic partnerships. ${ }^{4}$ The experience of INAM and UP-EIDR in developing BPGs thus offers significant insight into how community participation in the spirit of primary health care is implemented, while considering the need to provide health care services that are compatible with current scientific evidence, existing local and national health systems, and socio-cultural norms.

Table 1. Top ten (10) illnesses as specified in the best practice guidelines, and proposed initial management in the community setting

\begin{tabular}{|c|c|c|c|c|c|}
\hline Disease & $\begin{array}{l}\text { Filipino term } \\
\text { used in the } \\
\text { guidelines }\end{array}$ & $\begin{array}{l}\text { Salient features in } \\
\text { history and PE }\end{array}$ & $\begin{array}{l}\text { Initial referral criteria to } \\
\text { higher-level facilities }\end{array}$ & Proposed initial management & $\begin{array}{c}\text { Referral criteria after } \\
\text { initial management }\end{array}$ \\
\hline $\begin{array}{l}\text { Common } \\
\text { cough }\end{array}$ & $\begin{array}{l}\text { Karaniwang } \\
\text { ubo }\end{array}$ & $\begin{array}{l}\text { Self-limiting disease, } \\
\text { usually of } 2-7 \text { days } \\
\text { duration } \\
\text { Patients usually able } \\
\text { to continue working, } \\
\text { without loss of } \\
\text { appetite }\end{array}$ & $\begin{array}{l}\text { Rapid breathing or } \\
\text { dyspnea in children } \\
\text { More than } 2 \text { weeks } \\
\text { duration } \\
\text { Green, yellow or } \\
\text { blood-tinged sputum } \\
\text { Persistent cough that } \\
\text { hinders sleep }\end{array}$ & $\begin{array}{l}\text { Increased fluid intake } \\
\text { Use of medicinal plants } \\
\text { (sampalok, luya, kalamansi, } \\
\text { oregano, lagundi*) } \\
\text { Acupressure (head, chest, } \\
\text { and back) }\end{array}$ & $\begin{array}{l}\text { No improvement after } \\
3 \text { days } \\
\text { Persistent dyspnea, } \\
\text { fast breathing }\end{array}$ \\
\hline Influenza & Trangkaso & $\begin{array}{l}\text { Fever with } \\
\text { accompanied } \\
\text { malaise, headache, } \\
\text { nausea, cough, colds } \\
\text { and loose bowel } \\
\text { movement }\end{array}$ & $\begin{array}{l}\text { Special attention for } \\
\text { elderly and young } \\
\text { children } \\
\text { High index of suspicion } \\
\text { for dengue fever and } \\
\text { leptospirosis, based } \\
\text { on increased local } \\
\text { incidence, high-grade } \\
\text { fever, and rashes } \\
\text { Bleeding } \\
\text { Tea-colored urine, calf } \\
\text { tenderness, jaundice }\end{array}$ & $\begin{array}{l}\text { Increased fluid intake } \\
\text { Rest } \\
\text { Tepid sponge bath, using water } \\
\text { previously boiled with suha, } \\
\text { tanglad, kamyas* or other } \\
\text { medicinal plants } \\
\text { Acupressure of forehead, } \\
\text { temporal area, chest and back } \\
\text { Paracetamol }\end{array}$ & $\begin{array}{l}\text { Persistent dyspnea, } \\
\text { fast breathing }\end{array}$ \\
\hline Measles & Tigdas & $\begin{array}{l}\text { 10-12 days incubation } \\
\text { period } \\
\text { High-grade fever } \\
\text { Cough and colds } \\
\text { Red and watery eyes } \\
\text { that are highly } \\
\text { sensitive to light } \\
\text { Koplik's spot (defined } \\
\text { using local language) } \\
\text { Rashes that erupt } 4 \\
\text { days after fever onset } \\
\text { Loss of drive and } \\
\text { appetite }\end{array}$ & $\begin{array}{l}\text { All cases must be } \\
\text { reported to the local } \\
\text { health center }\end{array}$ & $\begin{array}{l}\text { Intake of nutritious food } \\
\text { Increased fluid intake } \\
\text { Tepid sponge bath, using water } \\
\text { previously boiled with suha, } \\
\text { tanglad, kamyas, kulantro* or } \\
\text { other medicinal plants } \\
\text { Face wash to alleviate eye } \\
\text { irritation } \\
\text { Paracetamol for high-grade fever } \\
\text { Vitamin A supplementation }\end{array}$ & $\begin{array}{l}\text { Persistent dyspnea and } \\
\text { fast breathing }\end{array}$ \\
\hline
\end{tabular}




\begin{tabular}{|c|c|c|c|c|c|}
\hline Disease & $\begin{array}{l}\text { Filipino term } \\
\text { used in the } \\
\text { guidelines }\end{array}$ & $\begin{array}{l}\text { Salient features in } \\
\text { history and PE }\end{array}$ & $\begin{array}{l}\text { Initial referral criteria to } \\
\text { higher-level facilities }\end{array}$ & Proposed initial management & $\begin{array}{l}\text { Referral criteria after } \\
\text { initial management }\end{array}$ \\
\hline $\begin{array}{l}\text { Pulmonary } \\
\text { tuberculosis }\end{array}$ & TB & $\begin{array}{l}\text { Cough of more than } 2 \\
\text { weeks duration } \\
\text { Feverish episodes in } \\
\text { the late afternoon } \\
\text { Loss of weight and } \\
\text { appetite (additional } \\
\text { considerations for } \\
\text { extrapulmonary TB } \\
\text { mentioned) }\end{array}$ & $\begin{array}{l}\text { All cases must be } \\
\text { referred to the health } \\
\text { center. }\end{array}$ & $\begin{array}{l}\text { Strictly supervised by a physician. } \\
\text { Supportive measures: } \\
\text { Diet, adequate rest, cessation of } \\
\text { smoking and alcoholic beverage } \\
\text { intake, regular visits to health } \\
\text { center } \\
\text { Acupressure on the "TB Point," } \\
\text { with anatomic landmarks } \\
\text { depicted }\end{array}$ & $\begin{array}{l}\text { As specified in health } \\
\text { center guidelines } \\
\text { (TB-DOTS) }\end{array}$ \\
\hline $\begin{array}{l}\text { Acute } \\
\text { gastroenteritis }\end{array}$ & Pagtatae & $\begin{array}{l}\text { Loose bowel } \\
\text { movement of } \\
\text { increased frequency } \\
\text { (more than } 3 \text { times } \\
\text { daily) }\end{array}$ & $\begin{array}{l}\text { Signs of extreme } \\
\text { dehydration (extreme } \\
\text { thirst, dryness of } \\
\text { mucus membranes, } \\
\text { sinking of eyeballs } \\
\text { and fontanelles, } \\
\text { decreased urine } \\
\text { output, poor skin } \\
\text { turgor) } \\
\text { Persistent vomiting } \\
\text { Blood-tinged, mucoid } \\
\text { or rice water stools }\end{array}$ & $\begin{array}{l}\text { Oral rehydration therapy or } \\
\text { breastfeeding } \\
\text { Use of medicinal plants } \\
\text { (tsaang gubat, bayabas, } \\
\text { mangosteen peel*) } \\
\text { Avoidance of anti-diarrheal } \\
\text { medications (e.g. loperamide) } \\
\text { and antibiotics without medical } \\
\text { consult } \\
\text { Nutritious diet } \\
\text { Preventive measures: sanitary } \\
\text { toilets, handwashing, proper } \\
\text { food and water handling }\end{array}$ & $\begin{array}{l}\text { Persistent signs of } \\
\text { dehydration }\end{array}$ \\
\hline $\begin{array}{l}\text { Intestinal } \\
\text { parasitism }\end{array}$ & Bulate & $\begin{array}{l}\text { Persistently } \\
\text { undernourished } \\
\text { children, with } \\
\text { enlarged abdomens, } \\
\text { stunting and pallor } \\
\end{array}$ & $\begin{array}{l}\text { Availment of school- } \\
\text { based and health } \\
\text { center-based } \\
\text { deworming programs }\end{array}$ & $\begin{array}{l}\text { Availment of school-based and } \\
\text { health center-based deworming } \\
\text { programs } \\
\text { Use of medicinal plants (niyog- } \\
\text { niyogan, ipil-ipil*) }\end{array}$ & $\begin{array}{l}\text { Information included } \\
\text { on identifying the } \\
\text { specific parasite, } \\
\text { availment of fecalysis } \\
\text { in health centers } \\
\end{array}$ \\
\hline Amebiasis & Amebiasis & $\begin{array}{l}\text { History of intake of } \\
\text { contaminated water } \\
\text { and produce (usually } \\
\text { fertilized by night } \\
\text { soil/human waste) } \\
\text { Blood-tinged or } \\
\text { mucoid stools } \\
\text { Constipation } \\
\text { Flu-like illness } \\
\end{array}$ & $\begin{array}{l}\text { All cases must } \\
\text { be referred to a } \\
\text { physician }\end{array}$ & $\begin{array}{l}\text { Referral to physician for } \\
\text { prescription of metronidazole } \\
\text { Supplementary use of papaya* } \\
\text { Cessation of alcohol intake } \\
\text { Nutritious diet } \\
\text { Personal sanitation }\end{array}$ & $\begin{array}{l}\text { No specified additional } \\
\text { referral criteria }\end{array}$ \\
\hline Scabies & $\begin{array}{l}\text { Kurikong o } \\
\text { galis-aso }\end{array}$ & $\begin{array}{l}\text { Pruritic lesions with } \\
\text { dark center, often } \\
\text { in intertriginous } \\
\text { areas, abdomen and } \\
\text { scrotal area } \\
\text { Intense itching at } \\
\text { nighttime }\end{array}$ & $\begin{array}{l}\text { No specified referral } \\
\text { criteria }\end{array}$ & $\begin{array}{l}\text { Use of medicinal plants } \\
\text { (makabuhay, kalatsutsi, } \\
\text { malunggay, kakawati*) } \\
\text { Use of permethrin } \\
\text { Sun-drying of beddings }\end{array}$ & $\begin{array}{l}\text { No specified referral } \\
\text { criteria }\end{array}$ \\
\hline Hypertension & Altapresyon & $\begin{array}{l}\text { Common in persons } \\
\text { with obesity, high- } \\
\text { stress lifestyle } \\
\text { At least } 2 \text { blood } \\
\text { pressure readings } \\
\text { of at least } 140 / 90 \\
\text { within one week }\end{array}$ & $\begin{array}{l}\text { The manual described } \\
\text { complications } \\
\text { associated with } \\
\text { hypertension: stroke, } \\
\text { heart disease, kidney } \\
\text { failure, blurring of } \\
\text { vision }\end{array}$ & $\begin{array}{l}\text { The manual provided instructions } \\
\text { on taking blood pressure, } \\
\text { healthy lifestyle and diet, and } \\
\text { smoking cessation } \\
\text { Use of medicinal plants (sambong, } \\
\text { tanglad, kogon, pandan, buhok } \\
\text { ng mais, bawang*) in cases of } \\
\text { pre-hypertension (lower than } \\
140 / 90 \text { ) } \\
\text { Use of reflexology massage, } \\
\text { acupressure }\end{array}$ & $\begin{array}{l}\text { Persistent blood } \\
\text { pressure above } \\
140 / 90 \\
\text { Referral for } \\
\text { prescription of } \\
\text { medications }\end{array}$ \\
\hline $\begin{array}{l}\text { Diabetes } \\
\text { mellitus }\end{array}$ & Diabetes & $\begin{array}{l}\text { Increased appetite } \\
\text { Frequent thirst } \\
\text { Frequent urination } \\
\text { Weight loss } \\
\text { Fasting blood glucose } \\
\text { level is higher than } \\
125 \mathrm{mg} / \mathrm{dL} \\
\text { Associated family } \\
\text { history, increased } \\
\text { intake of sugary } \\
\text { foods, lack of exercise }\end{array}$ & $\begin{array}{l}\text { All cases must } \\
\text { be referred to a } \\
\text { physician }\end{array}$ & $\begin{array}{l}\text { Diet and lifestyle modification, } \\
\text { and regular monitoring of } \\
\text { blood glucose } \\
\text { Use of ampalaya, banaba, luyang } \\
\text { dilaw, okra and sibukaw*, } \\
\text { acupressure or tui na massage } \\
\text { with physician supervision }\end{array}$ & $\begin{array}{l}\text { Persistently elevated } \\
\text { blood glucose level }\end{array}$ \\
\hline
\end{tabular}


Table 2. Selected medicinal plants included in the best practice guidelines

\begin{tabular}{|c|c|c|c|}
\hline Local name & Scientific name & Disease entity & Part of plant in use \\
\hline Ampalaya & Momordica charantia Linn. & Diabetes & Fruit and leaves (eaten) \\
\hline Bayabas & Psidium guajava Linn. & Acute gastroenteritis & Leaf (decoction taken orally) \\
\hline Bawang & Allium sativum $L$. & Hypertension & Cloves (eaten) \\
\hline Ipil-ipil & Leucaena leucocephala (Lam.) de Wit & Intestinal parasitism & Dried, mature seed (crushed and powdered, taken orally) \\
\hline Kakawati & Gliricidia sepium (Jacq.) Steud. & Scabies & Leaf or bark (extract applied to affected area) \\
\hline Kalamansi & Citrus x microcarpa Bunge & Common cough & Fruit (juice taken orally) \\
\hline Kalatsutsi & Plumeria acuminata W. T. Ait. & Scabies & Leaf or bark (extract applied to affected area) \\
\hline Kamyas & Averrhoa bilimbi L. & Influenza, measles & Leaf (decoction for tepid sponge bath) \\
\hline Kogon & Imperata cylindrica (L.) Raeusch & Hypertension & Root (decoction taken orally) \\
\hline Kulantro & Coriandrum sativum Linn. & Measles & Seed (decoction for tepid songe bath) \\
\hline Lagundi & Vitex negundo Linn. & Common cough & Leaf (decoction taken orally) \\
\hline Luya & Zingiber officinale Roscoe & Common cough & Rhizome (decoction taken orally) \\
\hline Luyang dilaw & Curcuma longa & Diabetes & Rhizome (used as tea drink) \\
\hline Mais & Zea mays & Hypertension & Hair (decoction taken orally) \\
\hline Makabuhay & Tinospora crispa (L.) Hook.F. \& Thomson & Scabies & Vine stalk (extract applied to affected area) \\
\hline Malunggay & Moringa oleifera Lam. & Scabies & Leaf or bark (extract applied to affected area) \\
\hline Mangosteen & Garcinia mangostana Linn. & Acute gastroenteritis & Dried peel (decoction taken orally) \\
\hline Niyog-niyogan & Quisqualis indica Linn. & Intestinal parasitism & Seed from dry, mature fruit (chewed and taken orally) \\
\hline Oregano & Plectranthus amboinicus (Lour.) Spreng. & Common cough & Leaf (juice taken orally) \\
\hline Papaya & Carica papaya Linn. & Amoebiasis & Seed of ripe fruit (crushed, mixed with water, taken orally) \\
\hline Sambong & Blumea balsamifera (Linn.) DC. & Hypertension & Leaf (decoction taken orally) \\
\hline Sampalok & Tamarindus indica Linn. & Common cough & Leaf (decoction taken orally) \\
\hline Suha & Citrus maxima (Burm.) Merr. & Influenza, measles & Leaf (decoction for tepid sponge bath) \\
\hline Tanglad & Cymbopogon citratus (DC.) Stapf & Influenza, measles & Leaf (decoction for tepid sponge bath) \\
\hline Tsaang gubat & Carmona retusa (Vahl.) Masam. & Acute gastroenteritis & $\begin{array}{l}\text { Leaf (decoction taken orally) } \\
\text { Leaf (decoction taken orally) }\end{array}$ \\
\hline
\end{tabular}

Table 3. Acupressure points included in the best practice guidelines

Disease entity Location $\quad$ Method*

\begin{tabular}{|c|c|c|}
\hline $\begin{array}{l}\text { Common cough, } \\
\text { influenza }\end{array}$ & $\begin{array}{l}\text { Forehead and temporal areas } \\
\text { Below the ear, neck area } \\
\text { Back }\end{array}$ & $\begin{array}{l}\text { Massage in an upward, circular motion } \\
\text { Pressure exerted by fingers } \\
\text { Massage using a downward direction }\end{array}$ \\
\hline $\begin{array}{l}\text { Pulmonary } \\
\text { tuberculosis }\end{array}$ & $\begin{array}{l}\text { "TB point": } 3.5 \mathrm{~cm} \text { lateral to C7 spinous process, intersecting an imaginary line } \\
\text { created by the medial edge of the right scapula }\end{array}$ & Massage \\
\hline \multirow[t]{5}{*}{ Hypertension } & Points proximal to the first digit of the foot & Pressure exerted by fingers \\
\hline & Area lateral to the antecubital fossa (elbow pit) & Pressure exerted by fingers \\
\hline & Forehead & Pressure exerted by fingers \\
\hline & Shoulder & Pressure exerted by fingers \\
\hline & Ear (specific acupressure points depicted in manual) & Pressure exerted by fingers \\
\hline \multirow[t]{2}{*}{ Diabetes } & $\begin{array}{l}\text { "Diabetes point": a point located } 1.5 \text { inches laterally from the midpoint of the } \\
\text { vertebral column, intersected by an imaginary line formed by the inferior } \\
\text { margin of the right scapula }\end{array}$ & Pressure exerted by fingers \\
\hline & Two pressure points in the medial region of the plantar aspect of the foot & Pressure exerted by fingers \\
\hline
\end{tabular}

${ }^{*}$ Note: All steps done in 5-minute intervals.

Moreover, like any other clinical practice guideline, BPGs must also be updated to reflect changing epidemiologic trends, new discoveries, and adverse events. ${ }^{3}$ Thus, the project emphasized due vigilance and diligence in implementing the BPGs, which includes monitoring any adverse effects, and updating its recommendations. Also, for this reason, a monitoring and evaluation component was introduced during the validation phase, which will hopefully generate information on the long-term applicability of the BPGs towards nationwide adoption, and the development of future updated versions. Admittedly, a reporting system for adverse effects was not included in this system, which we now recognize in hindsight. Tests to determine active ingredients and mechanisms of action of isolated compounds from identified medicinal plants, as well as community-wide supervised and documented clinical trials are also possible future directions for this project.

Remarkably, the experience also empowered communities to be involved in a process that facilitates assessment of cost of interventions in the community setting, since the BPG development process took steps that may be considered homologous to health technology assessment (HTA), a process used for costing conventional health interventions in the clinical setting that guide decision making in health financing. HTA relies on evidence of efficacy and effectiveness of interventions, factors promoting and impeding their 
implementation, and outcome measures ${ }^{13}$ and is used by health insurance organizations to make decisions on financing public health, including PhilHealth. Since universal health care in the Philippines is a concept that is usually delegated to PhilHealth for implementation, ${ }^{14}$ the development of a community-based process that is homologous to HTA holds promise as a model for gathering community-sourced inputs for costing clinical and public health interventions.

Meanwhile, because the BPGs also ensure consistency of practice across all CMHPs, it also paves the way for a semblance of professionalization of community health workers, which in turn facilitates support by national health financing schemes, while improving quality of health services. A case in point that successfully demonstrates this outcome is the accredited social health activist (ASHA) program launched by the Government of India in 2005, which recruited ASHA workers for every village with a population of 1000 , and which led to improvements in local health service delivery, as well as the opportunity to receive performance-based incentives. Accreditation is granted upon completion of a modular training program held in district hospitals and primary health care centers by a trained officer. Though its incentive scheme is linked with performance indicators and was therefore an "outcome-based remuneration structure," it nevertheless led to a remarkable increase in facility-based deliveries. ${ }^{15} \mathrm{We}$ think that the success of the ASHA program can be achieved even more as a result of developing BPGs, since the Philippines has a health financing scheme for accredited facilities that mandate the compensation of involved accredited health workers for every service rendered, and not due to subjective performance assessments. ${ }^{16}$ Therefore, by awarding PhilHealth health worker accreditation to community health workers who have undergone standardized modular programs like the PIM course offered by INAM, it is hoped that the capitation scheme of PhilHealth would help finance small community health centers that provide much-needed health services in rural and urban poor areas. Notwithstanding, this does not disregard the need to accredit, and thus fully equip, health facilities. This is admittedly a future direction for CMHPs, and which deserves further investigation.

Another aspect of the project that needs to be considered is how lessons from this project can be applied to the government sector and its barangay health worker (BHW) system, while considering variation across local health systems due to the devolved health system set-up in the Philippines. It must be noted that the CMHPs involved in the project are characterized by a less rigid organizational structure as compared to their local government counterparts, and thus practically wield considerable control in recruiting community health workers, while being constrained to innovate in response to health needs and in the face of possible funding challenges

Table 4. Selected disease-specific comments generated from stakeholders during the BPG development phase

\begin{tabular}{ll} 
Disease entity & $\begin{array}{c}\text { Comments from panel of reacto } \\
\text { Influenza }\end{array}$ \\
$\begin{array}{l}\text { There is a need to differentiate } \\
\text { between illnesses initially } \\
\text { presenting as flu-like illness }\end{array}$ \\
\hline Measles & $\begin{array}{l}\text { Guidelines must advocate for } \\
\text { vaccination, as per DOH } \\
\text { guidelines. }\end{array}$
\end{tabular}
guidelines.
Comments from government stakeholders (e.g. DOH, provincial and municipal LGUs) Comments from partner communities

Advice on flu vaccines should be given, as these are given free by $\mathrm{DOH}$ for senior citizens.

Aspirin must not be given to children because this had been linked to Reye's syndrome.

No comment given

\begin{tabular}{lc}
\hline Pulmonary & There is a need for an information \\
tuberculosis & campaign on how PTB is treated \\
& Persons with PTB must be referred \\
to the DOTS program in public \\
health centers.
\end{tabular}

Acute Signs of slight or moderate

gastroenteritis dehydration must be further explained

Tui na massage should be added as a complementary mode of treatment to boost immunity.

\begin{tabular}{|c|c|}
\hline Amebiasis & $\begin{array}{l}\text { The need to refer to a health } \\
\text { professional must be emphasized, } \\
\text { especially after unsuccessful trial } \\
\text { of medicinal plants. } \\
\text { Personal hygiene must be } \\
\text { emphasized in the guidelines. }\end{array}$ \\
\hline
\end{tabular}

Guidelines must advocate for vaccination, as per $\mathrm{DOH}$ guidelines.

Practical advice on preventing spread of the illness (especially for mothers or family members)

Information on the BCG vaccine must

Information on Vitamin A supplementation for infants ages 6-11 months old who have been diagnosed with measles should be included.

Volunteer health workers should report all patients with signs and symptoms of measles to the nearest health facility.

Patients should be referred for sputum collection and free anti-TB medications at the rural health units.

Guidelines should emphasize the assistive role of $\mathrm{CHWs}$ in treating PTB.

Case finding should be done among household contacts of patients positive for TB.

The term "severe diarrhea" must be well-defined.

Preparation of medicinal plants must be described in detail.

Information on environmental sanitation, hygiene, and sources of drinking water should be included.

The signs and symptoms of dehydration should be enumerated, with cases of severe dehydration needing urgent referral to the nearest health facility.

The recommendation should include the use of water-sealed toilets. Proper handwashing should also be emphasized and its steps illustrated clearly.

The use of herbal medicine must be No comment given used if there is no available doctor. The use of safe water must be included. 


\begin{tabular}{|c|c|c|c|}
\hline Disease entity & Comments from panel of reactors & Comments from partner communities & $\begin{array}{l}\text { Comments from government stakeholders } \\
\text { (e.g. DOH, provincial and municipal LGUs) }\end{array}$ \\
\hline $\begin{array}{l}\text { Intestinal } \\
\text { parasitism }\end{array}$ & $\begin{array}{l}\text { Tui na massage should also be } \\
\text { added as a mode of healing to } \\
\text { help increase immunity of the } \\
\text { patient. }\end{array}$ & $\begin{array}{l}\text { Various options for medicinal plants } \\
\text { must be included. } \\
\text { Different choices for herbs should be } \\
\text { described as this was based on the } \\
\text { experiences of different CHWs. }\end{array}$ & $\begin{array}{l}\text { Volunteer health workers should inform } \\
\text { mothers/caretakers of children 1-5 years old } \\
\text { regarding giving of antihelminthic drugs twice } \\
\text { a year. } \\
\text { Advice should also include refraining from the } \\
\text { practice of open defecation. }\end{array}$ \\
\hline Scabies & $\begin{array}{l}\text { The guidelines were cost-effective } \\
\text { and safe to use. }\end{array}$ & $\begin{array}{l}\text { Herbs that are not yet used for other } \\
\text { ailments should be highlighted. } \\
\text { Smaller fonts must be used if some } \\
\text { herbs are already being used for } \\
\text { other ailments. }\end{array}$ & No comment given \\
\hline Hypertension & $\begin{array}{l}\text { Patients with hypertension should } \\
\text { be referred for medications with } \\
\text { monthly follow-up. } \\
\text { Lifestyle modifications must be } \\
\text { emphasized (i.e. avoiding obesity, } \\
\text { sedentary lifestyle, and excessive } \\
\text { food intake). } \\
\text { For tui na, the length of time and } \\
\text { frequency should be specified. } \\
\text { For breathing exercises, the forms } \\
\text { of relaxation should be specified. }\end{array}$ & $\begin{array}{l}\text { The emphasis must be to refer } \\
\text { the patient to a doctor. CHWs } \\
\text { must teach the patient about } \\
\text { hypertension and should monitor } \\
\text { if medicines are being taken by } \\
\text { the patient. }\end{array}$ & No comment given \\
\hline Diabetes & $\begin{array}{l}\text { Testing and monitoring of blood } \\
\text { sugar levels should be done at } \\
\text { the community level. }\end{array}$ & $\begin{array}{l}\text { Eating junk food should be changed to } \\
\text { avoiding salty and fatty foods. } \\
\text { Guidelines should include waistline } \\
\text { recommendations from the DOH } \\
\text { Belly Good for Health program (e.g. } \\
\text { mean waistline of } 35 \text { for women } \\
\text { and } 40 \text { for men at risk of diabetes). }\end{array}$ & $\begin{array}{l}\text { One government stakeholder insisted the use of } \\
100 \mathrm{mg} / \mathrm{dL} \text { as diagnostic cut-off for diabetes, } \\
\text { not the specified } 120 \mathrm{mg} / \mathrm{dL} \text {. }\end{array}$ \\
\hline $\begin{array}{l}\text { Common cold } \\
\text { and cough }\end{array}$ & No comment given & $\begin{array}{l}\text { Further information and referral } \\
\text { criteria on dyspnea and fast } \\
\text { breathing should be included. } \\
\text { Avoidance of second-hand smoke and } \\
\text { the ill effects of passive smoking } \\
\text { should be emphasized. }\end{array}$ & $\begin{array}{l}\text { Increasing fluid intake must be emphasized in } \\
\text { the guidelines. } \\
\text { Cough of more than three days without } \\
\text { improvement, should be referred to the } \\
\text { nearest health center. } \\
\text { Herbal adjuncts to the treatment of cough } \\
\text { should not be given to infants below six } \\
\text { months old. } \\
\text { Any condition in children under } 5 \text { years old } \\
\text { should be consulted first with a physician. }\end{array}$ \\
\hline
\end{tabular}

that occasionally affect NGOs. ${ }^{17}$ This presents as a limitation to how government health facilities can apply lessons learned from this project on devolved local health systems, which are affected by local politics and funding priorities that may not always be compatible with public health interest. ${ }^{18}$ While the involvement of government stakeholders in the project represents a key milestone, the fact that it was limited only to local government units that host the CMHPs and national stakeholders that can only issue policy directions and provide technical assistance, demonstrates the bounds within which the BPG development process was carried out and can be confidently implemented.

Notwithstanding these difficulties, a key success factor in the project is the involvement of the academe, which lends substantial authority to the BPG development process. An important distinguishing component in this project is the fact that the communities themselves realized the need to collaborate with the academe and did not passively accept the need to develop practice standards. This ideal setting usually results from an established relationship between the communities and the academic partners, which therefore emphasizes the importance of long-term community engagement among academic institutions, which engender mutual trust and recognition of venues for improvement and innovation. Nonetheless, challenges that can adversely affect this relationship are long-term funding difficulties, as well as differing expectations on results dissemination. Tapp and colleagues consider this a case in point: when communities feel the need to disseminate preliminary results within the community, against the wishes of academic partners who are concerned about preserving group blinding to strengthen the case for any future conclusions. ${ }^{11}$ Drahota and colleagues add the following factors that adversely affect CAPs:

"excessive time commitment, excessive funding pressures or control struggles, unclear roles and/or functions of partners, poor communication among partners, inconsistent partner participation or membership, bigh burden of activities/tasks, distrust among partners, lack of shared vision, goals and or mission, lack of common or shared terms among partners, bad relationship among partners, and differing expectations of partners. "4 
On the other hand, facilitative factors that were identified were mutual trust, respect, and good relationships among collaborators, ${ }^{4}$ which in the practical sense and in our experience can only be achieved by good communication and a sustained relationship with partner communities.

Furthermore, community-academic partnerships demonstrate the importance of a so-called "nested approach," during which communities get acquainted with scientific methods practiced by their academic partners with regular opportunities for mentoring, thus generating a beneficial cascade of training opportunities and leading towards further linkage with stakeholders. ${ }^{19}$ At the same time, the academe gains skill in transmitting knowledge to a wide variety of audience, as well as venues for experiential learning and immersions for students, faculty, and staff; yet caution must be exercised to ensure that the communities would secure an equal stake in possible commercialization of products and technologies developed from CAPs. ${ }^{20} \mathrm{On}$ a more practical note, since academic institutions have contributed in some way to the intellectual formation of important stakeholders, especially in the case of UP for this project, academic institutions thus function as an effective bridge through which community interests may be transmitted to policy makers.

Indeed, due to the bridging role of academic institutions in this project, interest was generated among stakeholders such as the Philippine Institute for Traditional and Alternative Health Care and the Philippine Council for Health Research and Development to pursue further studies on the modalities included in the BPGs. This is in addition to how existing linkages between academe and government can facilitate LGU recognition of CMHPs as a health system complementing the existing network of barangay health stations, and PhilHealth accreditation of CMHP workers and facilities. Relating this to the previously cited challenge of applying this project to local government-run health systems, potential partners that allow for a workaround may be engaged through health research and development consortiums that were formed as a collaboration between academic institutions, science-oriented agencies, and the private sector, as implemented by the Philippine National Health Research System Act (Republic Act 10532). ${ }^{21}$ Factors that increase the success of these bridging opportunities need to be explored further, as these relationships are expected to be influenced by changing social norms, evolving technology and social media, and shift of political loyalties especially seen during changes in presidential administration.

\section{CONCLUSIONS AND RECOMMENDATIONS}

It is acknowledged that challenges remain in touting this project as a feasible program for full-fledged national implementation in view of issues that are especially applicable to the devolved Philippine health care system. Nevertheless, the underlying fact that this project is a community-academic partnership founded on community participation in the spirit of primary health care is a key element to its future success, due to its catalytic effect in engaging stakeholders and building evidence for health service delivery improvement. To further improve its applicability to other local health settings, it is thus recommended that other socio-cultural and political dimensions of community-academic partnerships and their linkage with stakeholders, as well as more detailed guidelines for the standardization of CMHP health service delivery and facilities be developed, to ensure the sustainability and continued updating of best practice guidelines, towards achieving scientifically sound and socially acceptable community health interventions.

\section{Acknowledgements}

The authors acknowledge the cooperation and participation of the CMHPs from the municipalities of Tanay, Gubat, Sorsogon City, Murcia, Sipalay, Sinacaban, Aloran, Midsayap, Patikul, and Jolo; partner organizations of INAM, and our research assistants and community organizers. This work was funded by the University of the Philippines through the Emerging Interdisciplinary Research Program of the Office of the Vice President for Academic Affairs under Grant C3-007, and with a contribution from Bread for the World-Protestant Development Service.

\section{Ethical Considerations}

Ethics clearance was secured from the UP-Manila Research Ethics Board under Protocol No. UPMREB 2015-076-01.

\section{Statement of Authorship}

All authors have approved the final version submitted.

\section{Author Disclosure}

All authors have declared no conflict of interest.

\section{Funding Source}

This paper was funded by the University of the Philippines through the Emerging Interdisciplinary Research Program of the Office of the Vice President for Academic Affairs.

\section{REFERENCES}

1. World Health Organization (WHO), Declaration of Alma-Ata [Online]. 1978 [cited 2017 October]. Available from http://www.who. int/publications/almaata_declaration_en.pdf?ua $=1$.

2. Reynolds J, DiLiberto D, Mangham-Jefferies L, et al. The practice of 'doing' evaluation: lessons learned from nine complex intervention trials in action. Implementation Science 2014; 9:75. doi: 10.1186/17485908-9-75.

3. Institute of Medicine (US) Committee to Advise the Public Health Service on Clinical Practice Guidelines; Field MJ, Lohr KN, editors. Washington (DC): National Academies Press (US); 1990 [cited 2017 October]. Available from: https://www.ncbi.nlm.nih.gov/books/ NBK235758/. 
4. Drahota A, Mesa R, Brikho B, et al. Community-Academic Partnerships: A Systematic Review of the State of the Literature and Recommendations for Future Research. Milbank Quarterly 2016; 94(1):163-214. doi: 10.1111/1468-0009.12184.

5. Angeles J. Katiwala program: an alternative solution to the health problem [Abstract]. Popul Forum. 1981;7(3):2-6.

6. Osteria T, Okamura J. Community based health care in the Philippine highlands: the Hanunuo Mangyans of Mindoro. Asia Pac J Public Health 1988;2(4):230-4.

7. Lacuesta M, Sarangani S, Amoyen N. A diagnostic study of the DOH health volunteer workers program [Abstract]. Philipp Popul J. 1993 JanDec;9(14):2636.

8. Arroyo A. We work for the barangay where we live [Abstract]. Integration. 1998 Spring;(55):52.

9. Jacobs B, Ir P, Bigdeli M, Annear P, Van Damme W. Addressing access barriers to health services: an analytical framework for selecting appropriate interventions in low-income Asian countries. Health Policy and Planning 2011;1-13. doi:10.1093/heapol/czr038

10. O'Brien M, Whitaker R. The role of community-based participatory research to inform local health policy: a case study. J Gen Intern Med. 2011 Dec;26(12):1498-501. doi: 10.1007/s11606-011-1878-3. Epub 2011 Sep 21.

11. Tapp H, White L, Steuerwald M, Dulin M. Use of community-based participatory research in primary care to improve healthcare outcomes and disparities in care. J Comp Eff Res. 2013 Jul; 2(4): 405-19.doi: 10.2217/cer.13.45

12. Integrative Medicine for Alternative Healthcare Systems Philippines, Inc. Our story. [Online]. [cited 23 Oct 2017] Available from http:// integratibmedisin.org/?page_id=6.

13. Perleth M, Jakubowski E, Busse R. ["Best practice" in health careor why we need evidence-based medicine, guidelines and health technology assessment (Abstract)]. Z Arztl Fortbild Qualitatssich. 2000 Oct;94(9):741-4.
14. Solon O, Panelo C, Gumafeliz E. A review of the Health Sector Reform Agenda (HSRA) implementation progress [Online]. 2003 [cited 2017 August]. Available from http://pdf.usaid.gov/pdf_docs/ Pnacu519.pdf.

15. Shrivastava SR, Shrivastava PS. Evaluation of trained Accredited Social Health Activist (ASHA) workers regarding their knowledge, attitude and practices about child health. Rural and Remote Health (Online) 2012; 12: 2099. [cited 2017 October]. Available: http://www. rrh.org.au/articles/subviewnew.asp?ArticleID =2099

16. Philippine Health Insurance Corporation. Philhealth Circular No. 010 s. 2012. 2012[Online]. [cited 2017 October]. Available from https:// www.philhealth.gov.ph/circulars/2012/circ10_2012.pdf.

17. International Institute for Sustainable Development. Funding issues. [Online]. 2013 [cited October 2017]. Available from https://www.iisd. org/business/ngo/funding.aspx.

18. Bossert T, Beauvais J. Decentralization of health systems in Ghana, Zambia, Uganda and the Philippines: a comparative analysis of decision space. Health Policy Plan. 2002 Apr;17(1):14-31.

19. Fouché C, Lunt N. Nested Mentoring Relationships: Reflections on a Practice Project for Mentoring Research Capacity amongst Social Work Practitioners. J Soc Work 2010 Sep; 10(2). doi: 10.1177/1468017310378780.

20. Perkmann M, Tartari V, McKelvey M, et al. Academic engagement and commercialisation: A review of the literature on universityindustry relations. Research Policy 2013; 42(2):423-42. doi: 10.1016/j. respol.2012.09.007.

21. Republic Act No. 10532. An Act Institutionalizing the Philippine National Health Research System. 2013. 